\title{
DELÍRICO EU LIRIO
}

Camilo Mattar Raabe ${ }^{1}$

Calabouço entre prédios e nesgas

pátina azul.

iscas de

cimos de

carbono

cismos

hidratado.

fosfóreos.

folhas em decomposição...

$\begin{array}{ll}\text { do mosto } & \text { cantam } \\ \text { passarinhos } & \text { os ninhos }\end{array}$

insetos

Poderia se dizer,

Como se...

Vésper-tino

amarelando azul.

Como se

uma fonte luminária

repartisse o outono

e atravessasse

seu séquito por

${ }^{1}$ Doutorando em Teoria da Literatura pela Pontifícia Universidade Católica do Rio Grande do Sul, bolsista do CNPq. 
Pesassossego

egitosos mares.

Como se

jovem, repartindo à lua

sua câmara cúbica

e lantejoulas.
DESASSOSSEGO 18 | DEZ/2017 | ISSN 2175-3180

DOI: http://dx.doi.org/10.11606/issn.2175-3180.v9i18p158-159

Se venta a chuva o afago de sua memória

Purpurina o céu com o sangue da terra.

Amaciando o ouvido sereno;

Temperando os perfumes da cidade.

Chuva... Chuva... Chuva...

Partilha tua presença no escorrer da noite. 